\title{
木材ーボルト接合における塑性域締付け軸力の 締付けトルク算定法*1
}

\author{
松原独歩 $* 2$, 若島嘉朗 $* 3$, 藤澤泰士 $* 3$, 清水秀丸*4, \\ 北守顕久*5, 石川浩一郎*6
}

\section{Tightening Torque Calculation Method for Plastic Clamp Force of Bolted Timber Joints*1}

\author{
Doppo Matsubara*2, Yoshiaki WaKashima*3, Yasushi FujISAwA*3, \\ Hidemaru SHIMizU*4, Akihisa KitAmorI*5 and Koichiro IshIKAWA*6
}

\begin{abstract}
A method for calculating plastic clamp force from tightening torque was presented by considering a bi-linear model obtained from experimental tightening torque-clamp force relationships. The practical applicability of the calculation method was verified by tightening tests of Cryptomeria japonica-bolted joints using metal washers of various sizes. Results were as follows : It was found that a ratio of sidelength (diameter) to thickness of metal washers ranging from 7.8 to 16.0 did not affect the torque coefficient. In addition, the ratio of maximum plastic torque coefficient to maximum elastic torque coefficient, $\gamma_{\max }$ and the ratio of minimum plastic torque coefficient to minimum elastic torque coefficient, $\gamma_{\min }$, which are elements of the calculation method, tended to increase depending on embedment into timber of metal washers in side-length (diameter) to thickness ratios of 10.0 (washer size : $32 \times$ t $3.2 \mathrm{~mm}$ ), 10.9 (washer size : $35 \times$ t $3.2 \mathrm{~mm}$ ) and 7.8 (washer size : $35 \times \mathrm{t} 4.5 \mathrm{~mm}$ ). Furthermore, calculated tightening torque values were verified by tightening tests using a digital torque wrench. As a result, plastic clamp force values obtained by experiment agreed with calculated values ranging from minimum clamp force $F_{\min }$ to maximum clamp force $F_{\max }$. However, the method of reducing variation in $\gamma_{\max }$ and $\gamma_{\min }$ remained to be investigated.
\end{abstract}

Keywords: bolted timber joints, metal washer, torque coefficient, tightening torque.

木材のボルト接合において，締付けトルクと締付け軸力の関係をバイリニアモデルとし，塑性 域締付け軸力を管理するための締付けトルク算定法を提案した。そしてワッシャーの辺長比を7.8 から18.8の範囲でパラメータとした12種類のワッシャーを対象としたスギーボルト接合の締付け 実験を行い, 提案算定法による計算值を検証した。結果, 辺長比7.8から16.0の範囲では, 弾性範 囲のトルク係数に影響を及ぼさないことがわかった。また算定法にて, 塑性域の最大トルク係数 と弾性域の最大トルク係数の比を $\gamma_{\max }$, 塑性域の最小トルク係数と弾性域の最小トルク倸数の比

*1 Received December 5, 2016 ; accepted January 30, 2017. 本研究の一部は第66回日本木材学会大会（2016年 3 月, 名古屋）で発表した。

*2（地独）東京都立産業技術研究センター Tokyo Metropolitan Industrial Technology Research Institute, Tokyo 135-0064, Japan

*3 富山県農林水産総合技術センター Toyama Prefectural Agricultural, Forestry \& Fisheries Research Center, Imizu 939-0311, Japan

*4 椙山女学園大学生活科学部 School of life studies, Sugiyama Jogakuen University, Nagoya 464-8662, Japan

*5 京都大学生存圈研究所 Research Institute for Sustainable Humanosphere, Kyoto University, Uji 611-0011, Japan

*6 福井大学工学部 School of engineering, University of Fukui, Fukui 910-8507, Japan

Corresponding Author: D. Matsubara(matsubara.doppo@iri-tokyo.jp) 
を $\gamma_{\min }$ と新たに定義し，それぞれはワッシャーのめり込みが進展するに伴い変動することがわか った。また辺長比10.0，10.9，7.8の条件下において $\gamma_{\max }, \gamma_{\text {min }}$ を設定し本算定法によってトルク 算定することで，塑性域締付け軸力を得られることがわかった。

\section{1. 緒言}

近年，主として木造住宅の壁にエネルギー吸収部 材を挿入して, 建物の減衰力を高め, 地震エネルギ 一を積極的に吸収することによって建物の損傷を低 減する制振技術の開発が進められ，そのニーズが急 速に高まっている1)。このような背景より，著者ら は，木材をボルト等で締付けて軸力（以下，締付け 軸力と呼ぶ）を発生させ，その締付け軸力に伴い木 材同士もしくは木材と鋼板との間に生じる摩擦抵抗 力を利用した制振壁の開発を進めている。これは, 摩擦抵抗は, 接合部の耐力および剛性を上昇させる と共に, 履歴減衰容量を上昇させるという効果に着 目したためである ${ }^{2-7)}$ 。しかし木材の摩擦抵抗を耐

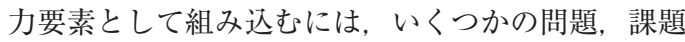
点が考えられる。

まず一点目は, 木材の応力緩和や乾燥収縮による 摩擦抵抗力を発現する締付け軸力の減少である。藤 元らは，ボルト接合の座金寸法㧍よび追締めが緩和 挙動に及ぼす影響について, 締付け直後に締付け軸 力緩和が大きく，その後緩やかに低下することを報 告している8)。Awaludin らは, 鋼板添え板ボルト 接合部の 1 年間の応力緩和実験を行い, 1 年後には 締付け軸力は大きく低下するが，仮に低下したとし ても，減衰容量は締付け軸力を与えない場合よりも 比較的高いとしている ${ }^{9)}$ 。また, 桑村は, ボルト接 合を想定して，木材を塑性変形させた上でさらに再 締付けを行った場合は, 応力緩和率が改善される傾 向にあることを報告している ${ }^{10)}$ 。さらに，著者らの これまでの実験では，木材をボルトで締付けて，木 材のめり込み降伏点を越える軸力（以下, 塑性域締 付け軸力と呼ぶ）を与えた場合は，高い応力を維持

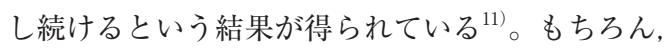
いずれの結果も長くても 1 年間程度の観察結果であ り, 乾湿繰り返しなどの非定常状態における緩和挙 動の追跡なども含めて今後のさらなる経過観察が必 要であろう。

二点目は，摩擦抵抗を発現する締付け軸力の管理 方法の問題である。著者らはこれまで, ボルト接合 を対象に,この締付け軸力と締付けトルクの関係を 定量的に調べ，締付け軸力はトルクレンチなどの工 具を用いて管理するいわゆるトルク法で制御可能で あり, 締付けトルクはトルク係数とボルト径抢よび
締付け軸力から決定できることを明らかにした ${ }^{12)}$ また，締付け速度を $20 \mathrm{rpm}$ に設定することで，締 付け軸力のばらつきを小さくすることが可能である ことを明らかにした ${ }^{13)}$ 。このトルク法は, 実用レベ ルにおいて簡便な管理法であると言えるが，いずれ の研究も限定条件下かつ弾性範囲内での結果であ り，著者らが検討を進めている木材の塑性域締付け 軸力をトルク法で管理可能なのか不明であった。ま た，ボルトで締付ける場合，ワッシャーがめり込む が, ワッシャーの辺長比（辺長/厚さ）が異なると ワッシャーのめり込み剛性や耐力が変化することが 分かっている ${ }^{14)}$ 。そのため, ワッシャーの辺長比の 違いによって，トルク係数に影響を及ぼす可能性が 考えられるが，この点についても定量的に把握でき ずにいた。ここで， 既報13) で得られたカラマッー ボルト接合の締付けトルクと締付け軸力の関係を Fig. 1 に示す。Fig. 1 によれば, 締付け軸力の上昇 に伴い締付けトルクも上昇していて, 弾性域以降で 勾配が変化しているように見える。この関係より， 締付けトルクと締付け軸力の関係をバイリニアモデ ルで表されるものとすれば，比較的簡便な塑性域締 付け軸力の締付けトルク算定式が得られると考えら れる。

そこで, この研究では, 木材のボルト接合につい て, 締付けトルクと締付け軸力の関係をバイリニア モデルで表し，木材の塑性域締付け軸力を管理する ための締付けトルク算定法を提案する。そして, ワ ッシャーの辺長比をパラメータとした締付け実験を 木材のめり込み降伏点を越える塑性域まで行うこと

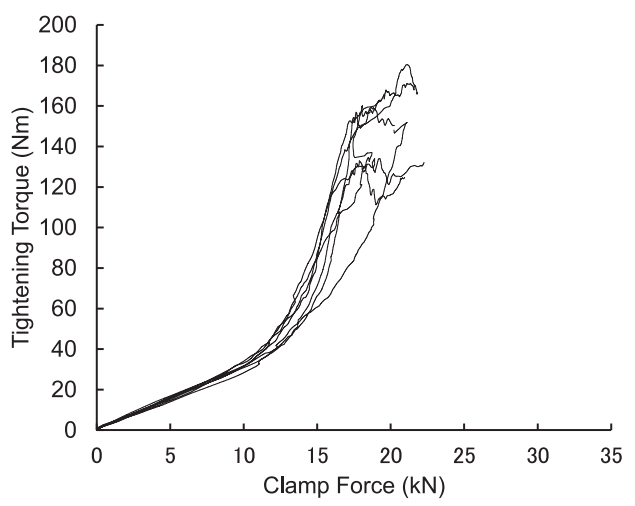

Fig. 1. Relationship between tightening torque and clamp force of Larix kaempferi-bolted joints. 
で， ワッシャーの辺長比の違いによってトルク係数 などにどのような影響を与えるのか実験的に把握す ると共に，提案算定式による計算値を検証した。

\section{2. 塑性域締付け軸力を管理するための 締付けトルク算定法}

著者らのこれまでの木材ボルト接合の締付け実験 結果より ${ }^{13)}$, Fig. 2 に示すように，木材のボルト接 合の締付けトルク $T_{\mathrm{f}}$ と締付け軸力 $F_{\mathrm{f}} d$ の関係は, 降伏締付け軸力 $F_{\mathrm{y}} d$ を越えた後, トルク係数 $K_{\mathrm{f} 1}$ と 異なる勾配で塑性域勾配が変化するというバイリニ アモデルで表されるものとすると, 塑性域締付け軸 力 $F_{\mathrm{fp}}$ を得るための目標締付けトルク $T_{\mathrm{A}}$ は以下の (1)式のように表すことができる。

$T_{\mathrm{A}}=d\left\{K_{\mathrm{f} 2}\left(F_{\mathrm{fp}}-F_{\mathrm{y}}\right)+K_{\mathrm{fl}} F_{\mathrm{y}}\right\} \quad \cdots(1)$

ここで，各記号について， $d$ はボルト径， $K_{\mathrm{f} 2}$ は塑 性域トルク係数と新たに定義し， $F_{\mathrm{y}}$ は降伏締付け 軸力, $K_{\mathrm{fl}}$ は弾性域のトルク係数である。

Fig. 2 に示したように， $K_{\mathrm{f} 1}$ および $K_{\mathrm{f} 2}$ はそれぞれ 最大值 $K_{\mathrm{fl} \max }, K_{\mathrm{f} 2 \max }$ と最小值 $K_{\mathrm{fl} \min }, K_{\mathrm{f} 2 \min }$ で変動 するものと考えられる。そのため, Fig. 2 に示した 着色部の範囲, すなわち $F_{\text {min }}, F_{\text {max }}$ の範囲で初期締 付け軸力は変動しばらつく。これがトルク管理法の 特徵で, 弾性範囲のトルク管理法によって得られる 締付け軸力についても，ばらつくことがよく知られ ていて各トルク係数を適切に評価することが重要と

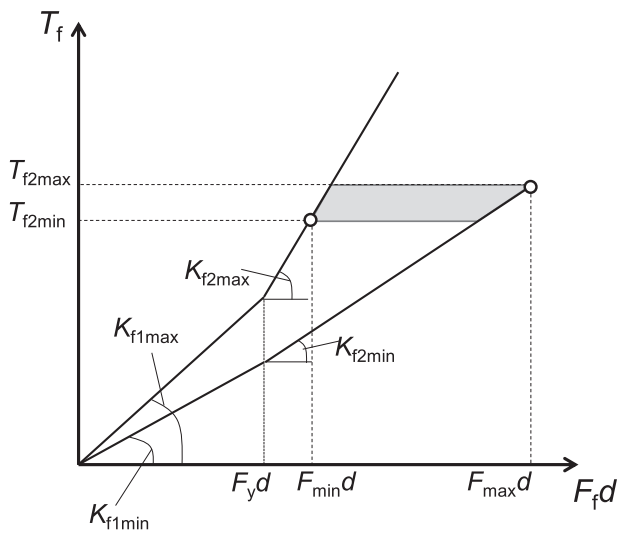

Fig. 2. Bi-linear model of the relationship between tightening torque and clamp force on bolted timber joints.

Notes: $F_{\max }$ : target maximum plastic clamp force, $F_{\mathrm{y}}$ : yield clamp force, $K_{\mathrm{fl} \max }$ : maximum torque coefficient, $K_{\text {flmin }}$ : minimum torque coefficient, $F_{\min }$ : target minimum plastic clamp force, $T_{\mathrm{f} 2 \max }$ : maximum plastic tightening torque, $T_{\mathrm{f} 2 \min }$ : minimum plastic tightening torque, $d$ : bolt diameter.
なる。ここで, Fig. 2 の $F_{\max }$ を目標最大塑性域締付 け軸力, $F_{\text {min }}$ を目標最小塑性域締付け軸力と定義す る。トルク管理法は，初期締付け軸力が少なくとも $F_{\text {min }}$ 以上， $F_{\text {max }}$ 以下となるように軸力を管理する方 法であるが, この研究では塑性域締付け軸力を少な くとも得られることを保証する目的のため，まず下 限の $F_{\min }$ をあらかじめ設定する必要がある。この時, $F_{\min }$ は $F_{\mathrm{y}}$ 以上を設定する。そして上限の $F_{\text {max }}$ を計 算し，それぞれに必要なトルクを計算し，目標締付 けトルク $T_{\mathrm{A}}$ を決定するという計算手順をとる。

まず，目標締付けトルク $T_{\mathrm{A}}$ は， $F_{\max }$ を得るため の最大塑性域締付けトルク $T_{\mathrm{f} 2 \text { max }}$ および $F_{\text {min }}$ を得 るための最小塑性域締付けトルク $T_{\mathrm{f} 2 \mathrm{~min}}$ の平均值と 設定すると、

$T_{\mathrm{A}}=\frac{T_{\mathrm{f} 2 \max }+T_{\mathrm{f} 2 \min }}{2} \cdots$

となる。

$T_{\mathrm{f} 2 \max }$ は, Fig. 2 より，(1)式を用いて以下の(3) 式 で表される。

$T_{\mathrm{f} 2 \max }=d\left\{K_{\mathrm{f} 2 \min }\left(F_{\max }-F_{\mathrm{y}}\right)+K_{\mathrm{f} 2 \min } F_{\mathrm{y}}\right\} \quad \cdots(3)$

$T_{\mathrm{f} 2 \mathrm{~min}}$ は, Fig. 2 より，（1)式より以下の(4)式で表 される。

$T_{\mathrm{f} 2 \min }=d\left\{K_{\mathrm{f} 2 \max }\left(F_{\min }-F_{\mathrm{y}}\right)+K_{\mathrm{f} 2 \max } F_{\mathrm{y}}\right\} \quad \cdots(4)$

一方, $T_{\mathrm{f} 2 \max }$ と $T_{\mathrm{f} 2 \min }$ は, トルク法で管理する場合, 次のような関係にある。すなわち，トルクレンチな どの様々な工具が用いられるが，トルクレンチによ るトルクの誤差率を $m$ とし, 締付けトルク $T_{\mathrm{A}}$ は, トルクレンチの誤差で強く締付け過ぎても $T_{\mathrm{f} 2 \max }$ 以 下に，小さく締付け過ぎても $T_{\mathrm{f} 2 \mathrm{~min}}$ 以上としなけれ ばならないので,

$T_{\mathrm{A}}\left(1+\frac{m}{100}\right) \leqq T_{\mathrm{f} 2 \max } \quad \cdots(5)$

$T_{\mathrm{A}}\left(1-\frac{m}{100}\right) \geqq T_{\mathrm{f} 2 \min } \quad \cdots(6)$

と表される。ここで，トルクレンチの誤差を考慮し た $T_{\mathrm{A}}$ の上限と下限が $T_{\mathrm{f} 2 \max }$ と $T_{\mathrm{f} 2 \min }$ に対応したと き等号が成立するので，(5)，（6)式より，

$\frac{T_{\mathrm{f} 2 \max }}{\left(1+\frac{m}{100}\right)}=\frac{T_{\mathrm{f} 2 \min }}{\left(1-\frac{m}{100}\right)} \ldots$

よって, $T_{\mathrm{f} 2 \max }$ は,

$T_{\mathrm{f} 2 \max }=\frac{\left(1+\frac{m}{100}\right)}{\left(1-\frac{m}{100}\right)} T_{\mathrm{f} 2 \min } \cdots(8)$

となるので，(3)，(4)式を(8) 式に代入し， $F_{\text {max }}$ に ついて解けば，以下の (9) 式を得る。 
$\frac{\frac{\left(1+\frac{m}{100}\right)}{\left(1-\frac{m}{100}\right)} K_{\mathrm{f} \max } F_{\min }-F_{\mathrm{y}}\left(\left(\frac{1+\frac{m}{100}}{1-\frac{m}{100}}\right) K_{\mathrm{f} \max }-\left(\frac{1+\frac{m}{100}}{1-\frac{m}{100}}\right) K_{\mathrm{ffmax}}-K_{\mathrm{f} \min }+K_{\mathrm{f} \min }\right)}{K_{\mathrm{f} 2 \min }}$

ここで，（9）式を見ると，未知数は $K_{\mathrm{f} 2 \max }, K_{\mathrm{f} 2 \min }$,

$K_{\mathrm{fl} \max }, K_{\mathrm{f} 1 \min }, F_{\mathrm{y}}$ の 5 つである。そこで, $K_{\mathrm{f} 2}$ と $K_{\mathrm{f} 1}$ の関係について, $\mathrm{K}_{\mathrm{f} 2 \max }$ と $K_{\mathrm{flm} \text { max }}$ の比を塑性域最大 トルク係数比 $\gamma_{\text {max }}\left(=K_{\mathrm{f} 2 \max } / K_{\mathrm{fl} \max }\right), K_{\mathrm{f} 2 \min }$ と $K_{\mathrm{fl} \min }$ の比を塑性域最小トルク係数比 $\gamma_{\text {min }}\left(K_{\mathrm{f} 2 \mathrm{~min}} / K_{\mathrm{fl} \min }\right)$ と定義する。すると， $F_{\text {max }}$ は $(10)$ 式となる。

$F_{\max }=$

$\frac{\left(1+\frac{m}{100}\right) K_{\mathrm{fl} \max }\left\{\gamma_{\max } F_{\min }+\left(1-\gamma_{\max }\right) F_{\mathrm{y}}\right\}+\left(1-\frac{m}{100}\right) K_{\mathrm{flmin}} F_{\mathrm{y}}\left(\gamma_{\min }-1\right)}{\left(1-\frac{m}{100}\right) \gamma_{\min } K_{\mathrm{fl} \min }}$

また， $T_{\mathrm{f} 2 \max }$ および $T_{\mathrm{f} 2 \min }$ は，同様に $\gamma_{\text {max }}, \gamma_{\text {min }}$ を 用いて表せば，それぞれ(11)，（12)式となる。

$T_{\mathrm{f} 2 \max }=d K_{\mathrm{f} 1 \min }\left\{\gamma_{\min } F_{\max }+\left(1-\gamma_{\text {min }}\right) F_{\mathrm{y}}\right\} \quad \cdots$

$T_{\mathrm{f} 2 \min }=d K_{\mathrm{fl} \max }\left\{\gamma_{\max } F_{\min }+\left(1-\gamma_{\max }\right) F_{\mathrm{y}}\right\}$

ここで， $K_{\mathrm{fl} \max }$ および $K_{\mathrm{fl} \min }$ は，ボルトとワッシ ヤーの接触面すなわち座面の摩擦係数 $\mu_{\mathrm{b}}$, ボルト とナットの接触面すなわちねじ面の摩擦係数 $\mu_{\mathrm{th}}$ に よってばらつくことが既報13) より明らかで， $K_{\mathrm{fl} \text { max }}$ および $K_{\mathrm{f} 1 \mathrm{~min}}$ は， $\mu_{\mathrm{b}}, \mu_{\mathrm{th}}$ のそれぞれの最大值と最

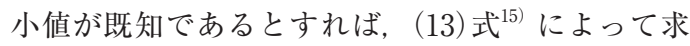
めることができる。

$K_{\mathrm{fl}}=\frac{1}{d}\left(\frac{P}{2 \pi}+0.577 \mu_{\mathrm{th}} d_{2}+0.5 \mu_{\mathrm{b}} D_{\mathrm{b}}\right) \quad \cdots$

ここで，Pはねじピッチ， $d_{2}$ はねじの有効径の基 準寸法, $D_{\mathrm{b}}$ はナット座面の摩擦に対する直径であ り(14)式昼)によって表される。

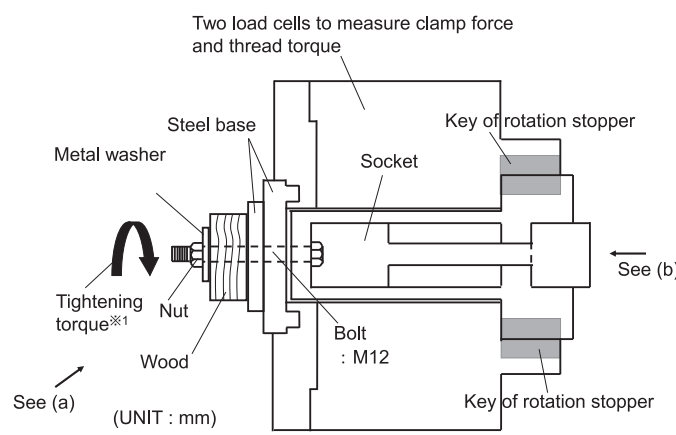

$D_{\mathrm{b}}=\frac{D_{0}+d_{\mathrm{h}}}{2} \cdots$

$D_{0}$ はナット座面の外径, $d_{\mathrm{h}}$ はワッシャーのボルト 穴径である。

$\mu_{\mathrm{b}}, \mu_{\mathrm{th}}$ が既知でなければ, トルク係数 $K_{\mathrm{fl} \max }$, $K_{\mathrm{fl} \min }$ は仕様毎に実験によって求める。この研究で は, ワッシャーの辺長比が $K_{\mathrm{f} 1}, K_{\mathrm{f} 2}$ にどのような 影響を与えるのか調べるので，実験より $K_{\mathrm{f} 1}, K_{\mathrm{f} 2}$ を 算出すると共に, $F_{\mathrm{y}}$ についても実験によって求め る。一方, $\gamma_{\max }, \gamma_{\text {min }}$ は, 例えば $\mu_{\mathrm{b}}$ が, 塑性域で ナットの回転によってワッシャーの表面が削られる などすれば, 值が大きく変動するものと推測される。 そこで, $\gamma_{\max }, \gamma_{\min }$ についても実験によって算出し, 以下その傾向を調べる。

\section{3. 実験}

供試材に用いる木材はスギ Cryptomeria japonica）とした。接線方向（T） $45 \mathrm{~mm}$, 半径方 向（R） $30 \mathrm{~mm}$, 繊維方向 (L) $200 \mathrm{~mm}$ とし, 室温 $20^{\circ} \mathrm{C} \pm 2^{\circ} \mathrm{C}$ の恒温室に約 1 力月間放置し, Fig. 3 に 示すような位置に直径 $13 \mathrm{~mm}$ のボルト孔を空けた。 ここで, 養生室の湿度はコントロールしていないが, 養生期間中の湿度は 41 ～55\%であった。平均密度は $362 \mathrm{~kg} / \mathrm{m}^{3}$ (標準偏差 $40.9 \mathrm{~kg} / \mathrm{m}^{3}$ ), 平均含水率は 10.8\%（標準偏差 $0.96 \%$ ）であった。

ボルトは M12の半ネジ六角ボルトで長さ $85 \mathrm{~mm}$,

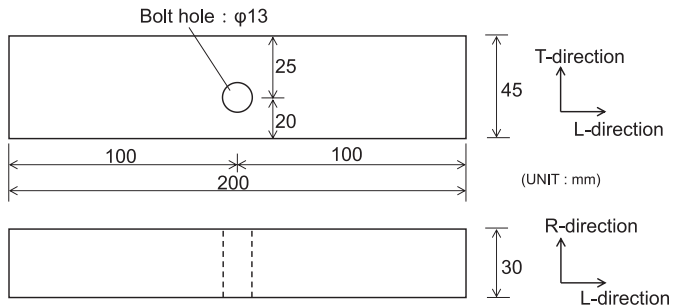

Fig. 3. Details of the test piece.

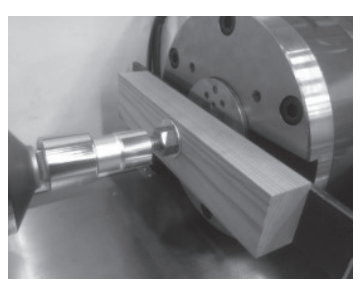

(a)

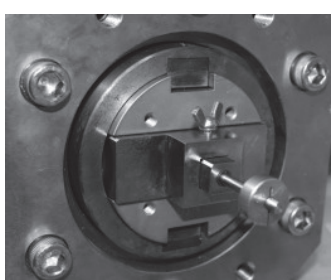

(b)

Fig. 4. Method of tightening test on bolted timber joints.

Note: ${ }^{* 1}$ : Encoder for measuring angles and load cell for measuring tightening torque. 
材質は SWCH とした。表面は亜鉛メッキの上にク ロメート処理され, ねじピッチは $1.75 \mathrm{~mm}$, 胴部径 は11.75 mmのものであった。ワッシャーは, 30 $\mathrm{mm} \times \mathrm{t} 1.6 \mathrm{~mm}, \quad 30 \mathrm{~mm} \times \mathrm{t} 2.3 \mathrm{~mm}, 32 \mathrm{~mm} \times$ t $2.0 \mathrm{~mm}, 32 \mathrm{~mm} \times \mathrm{t} 3.2 \mathrm{~mm}, 35 \mathrm{~mm} \times \mathrm{t} 3.2 \mathrm{~mm}$, $35 \mathrm{~mm} \times \mathrm{t} 4.5 \mathrm{~mm}$ の 6 種類の寸法形状を持つ, 角ワ ッシャーおよび丸ワッシャーを用い，材質は SPCC とした。ここで, ワッシャーの辺長比（辺長/厚さ） はそれぞれ順に18.8，13.0，16.0，10.0，10.9，7.8で ある。丸ワッシャーの場合は, ワッシャーの径長比 （ワッシャー径/厚さ）と呼ぶのが表現上適切かと 思われるが, 後述の考察で混乱を避けるために, こ の研究では, 角ワッシャー, 丸ワッシャーまとめて 辺長比と呼ぶことにする。各ワッシャーのボルト穴 径は $13.5 \mathrm{~mm}$ とした。ワッシャーの表面仕上げは亜 鉛メッキの上にクロメート処理されたものであっ た。ナットは 2 面幅 $18.7 \mathrm{~mm}$ であり, 表面メッキ仕 上げ無しの物で, 材質はボルトと同じ SWCH を用 いた。

実験には，ねじ締付け試験機（日本計測システム (侏) NST-500NM) を用いた。Fig. 4 に示すように，
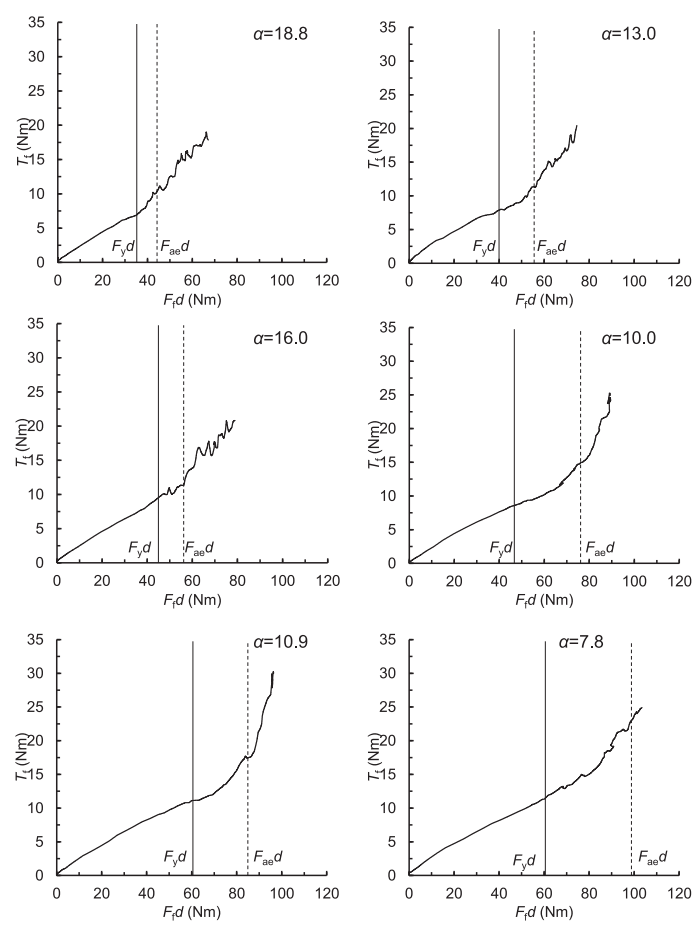

(a) Square washer
六角ボルト頭を治具にて回転しないように拘束し， ナット側を締付けた。ナット側の締付けトルク $T_{\mathrm{f}}$ と回転角 $\theta$ をそれぞれ計測した。また, ボルト頭と 木材の間に装着したロードセルにより締付け軸力 $F_{\mathrm{f}}$ およびねじ部トルク $T_{\mathrm{th}}$ を計測した。試験開始前 にナットを手締めし, 締付け軸力が約 $10 \mathrm{~N}$ に到達 した時点で手締めをやめて, それを初期点（トルク 值, 軸力值, 回転角值をゼロ）とし締付け実験を開 始した。締付け方向はR方向とした。締付け速度は, 既報 ${ }^{13)}$ より，20 rpm とした。試験は, 締付け回転 角が1100 deg（3 回転）に到達するまで行った。供

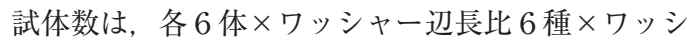
ヤー 2 形状の72体とした。

\section{4. 結果と考察}

\section{1 ワッシャーの辺長比が締付け特性に及ぼす影響}

4.1.1降伏締付け軸力時までの締付け挙動に及ぼ す影響

Fig. 5(a)，（b）に本実験で得られた締付けトルク $T_{\mathrm{f}}(\mathrm{Nm})$ と締付け軸力 $F_{\mathrm{f}}$ にボルト径 $d(0.012 \mathrm{~m})$ を乗じた值 $F_{\mathrm{f}} d(\mathrm{Nm})$ の代表的な関係を示す。ここ
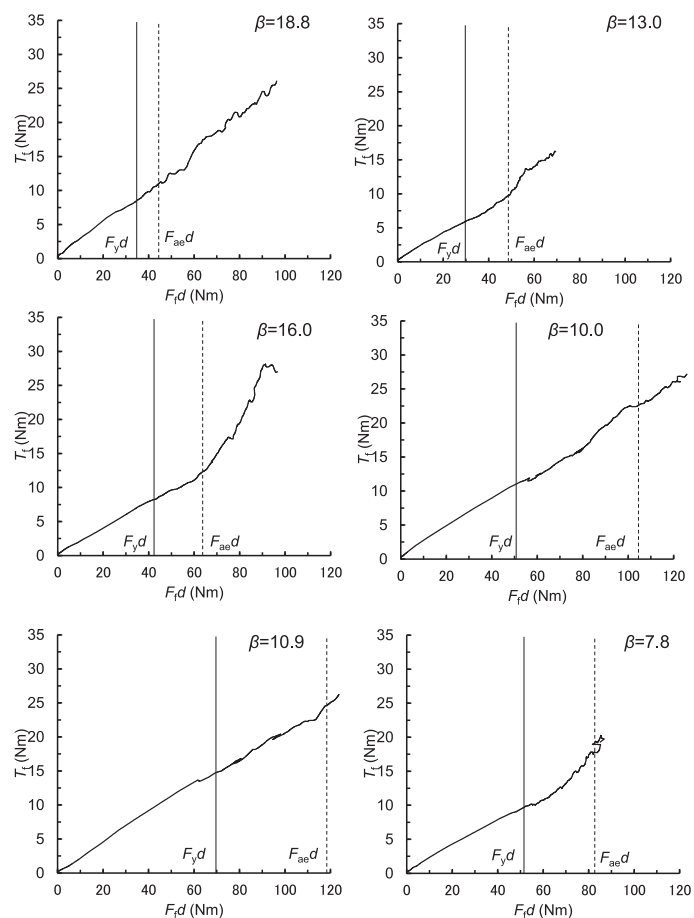

(b) Circular washer

Fig. 5. Relationship between tightening torque and clamp force.

Notes : $\alpha$ : side-length/thickness ratio of metal washer, $\beta$ : diameter/thickness ratio of circular washer, $F_{\mathrm{y}}:$ yield clamp force, $F_{\text {ae }}$ : clamp force on washer thickness embedment into timber, $d$ : bolt diameter. 
Table 1(a). Experimental values of $K_{\mathrm{fl}}, F_{\mathrm{y}}, K_{\mathrm{te}}$ and $K_{\mathrm{pe}}$ of square washers.

\begin{tabular}{|c|c|c|c|c|c|c|c|c|}
\hline \multirow{2}{*}{ Metal washer } & Side-length & Thickness & \multirow{2}{*}{$\alpha$} & & \multirow{2}{*}{$K_{\mathrm{f} 1}$} & $F_{\mathrm{y}}$ & $K_{\text {te }}$ & $K_{\mathrm{pe}}$ \\
\hline & $\mathrm{mm}$ & $\mathrm{mm}$ & & & & $\mathrm{kN}$ & $\mathrm{N} / \mathrm{deg}$ & $\mathrm{N} / \mathrm{deg}$ \\
\hline \multirow{24}{*}{ Square washer } & \multirow{4}{*}{30} & \multirow{4}{*}{1.6} & \multirow{4}{*}{18.8} & Max. & 0.257 & 3.24 & 8702 & 741 \\
\hline & & & & Min. & 0.183 & 2.86 & 5266 & 597 \\
\hline & & & & Avg. & 0.209 & 3.05 & 6593 & 686 \\
\hline & & & & Std. & 0.026 & 0.16 & 1131 & 56 \\
\hline & \multirow{4}{*}{30} & \multirow{4}{*}{2.3} & \multirow{4}{*}{13.0} & Max. & 0.214 & 3.79 & 8907 & 885 \\
\hline & & & & Min. & 0.171 & 3.11 & 6974 & 638 \\
\hline & & & & Avg. & 0.195 & 3.46 & 7550 & 758 \\
\hline & & & & Std. & 0.017 & 0.23 & 721 & 99 \\
\hline & \multirow{4}{*}{32} & \multirow{4}{*}{2.0} & \multirow{4}{*}{16.0} & Max. & 0.226 & 4.67 & 9175 & 761 \\
\hline & & & & Min. & 0.176 & 3.28 & 4999 & 597 \\
\hline & & & & Avg. & 0.198 & 3.75 & 7142 & 706 \\
\hline & & & & Std. & 0.021 & 0.48 & 1484 & 56 \\
\hline & \multirow{4}{*}{32} & \multirow{4}{*}{3.2} & \multirow{4}{*}{10.0} & Max. & 0.226 & 4.39 & 10491 & 1029 \\
\hline & & & & Min. & 0.173 & 3.53 & 7097 & 823 \\
\hline & & & & Avg. & 0.191 & 3.81 & 8349 & 929 \\
\hline & & & & Std. & 0.019 & 0.33 & 1464 & 84 \\
\hline & \multirow{4}{*}{35} & \multirow{4}{*}{3.2} & \multirow{4}{*}{10.9} & Max. & 0.241 & 5.18 & 10759 & 987 \\
\hline & & & & Min. & 0.198 & 4.45 & 7179 & 782 \\
\hline & & & & Avg. & 0.219 & 4.81 & 8558 & 885 \\
\hline & & & & Std. & 0.019 & 0.34 & 1289 & 80 \\
\hline & \multirow{4}{*}{35} & \multirow{4}{*}{4.5} & \multirow{4}{*}{7.8} & Max. & 0.212 & 5.13 & 9669 & 1008 \\
\hline & & & & Min. & 0.177 & 4.20 & 7653 & 843 \\
\hline & & & & Avg. & 0.194 & 4.75 & 8890 & 919 \\
\hline & & & & Std. & 0.013 & 0.32 & 744 & 67 \\
\hline \multirow{4}{*}{ All specimen } & & & & Max. & 0.257 & & & \\
\hline & & & & Min. & 0.171 & & & \\
\hline & & & & Avg. & 0.201 & & & \\
\hline & & & & Std. & 0.021 & & & \\
\hline
\end{tabular}

Notes : $\alpha$ : side-length / thickness ratio, $K_{\mathrm{f} 1}$ : torque coefficient, $F_{\mathrm{y}}$ : yield clamp force, $K_{\mathrm{te}}$ : elastic tightening stiffness, $K_{\mathrm{pe}}$ : plastic tightening stiffness, Max. : maximum, Min. : minimum, Avg.: average, Std. : standard deviation.

で，図の縦実線は，降伏締付け軸力（以下， $F_{\mathrm{y}} d$ と する）を示しているが, $F_{\mathrm{y}}$ は, 次の方法で算出した。 まず, Fig. 6 の締付け軸力と回転角の関係より, 初 期のスナグ点 ${ }^{15)}$ を越え直線的に増加した後，降伏 を迎え再び直線的に増加するという木材のめり込み 特性によく見られる挙動が全ての供試体で見られ た。そこで，この関係より，弾性域の 1 次勾配（以 下，締付け弾性剛性と定義し $K_{\mathrm{te}}(\mathrm{N} / \mathrm{deg})$ とする） を目視で直線域と判断した区間 $0.8 〜 2 \mathrm{kN}$ から最小 二乗法によって得て, 降伏後の 2 次勾配（以下，締 付け塑性剛性と定義し $K_{\mathrm{pe}}(\mathrm{N} / \mathrm{deg})$ とする）は回 転角300 deg から最大回転角1100 deg までの勾配を 同様に最小二乗法によって得て, それぞれの 2 直線 間の交点を $F_{\mathrm{y}}$ とした。

Fig. 5(a)，（b)より，辺長比の大小に関わらず, 原点から $F_{\mathrm{y}} d$ 間はほぼ直線的に, 締付け軸力の増大 に従い締付けトルクも上昇していることがわかる。
この原点から $F_{\mathrm{y}} d$ 間の直線勾配がトルク係数 $K_{\mathrm{f} 1}$ で あり, $K_{\mathrm{f} 1}$ は, 以下の $(15)$ 式12,13) により評価される。 $K_{\mathrm{fl}}=\frac{T_{\mathrm{f}}}{F_{\mathrm{f}} d} \quad \cdots \cdot$

ここで, $T_{\mathrm{f}}$ は締付けトルク, $F_{\mathrm{f}}$ は締付け軸力である。 そこで $K_{\mathrm{f} 1}$ について，前述の $K_{\mathrm{te}}$ を算出した時と 同様の区間を最小二乗法によって算出した。 $K_{\mathrm{f} 1}$ と 辺長比の関係を Fig. 7 に示す。また, Table $1(\mathrm{a})$, (b)に辺長比毎の $K_{\mathrm{f} 1}$ および前述した $F_{\mathrm{y}}, K_{\mathrm{te}}, K_{\mathrm{pe}}$ の結果一覧も併せて示した。これによれば，辺長比 の大小あるいはワッシャーの形状（角ワッシャーま たは丸ワッシャー）の違いと $K_{\mathrm{f} 1}$ との間には明確な 関係は認められなかった。 $K_{\mathrm{f} 1}$ の全供試体の平均值 は0.206, 標準偏差0.030となった。しかし, 辺長比 18.8 の 丸ッシャーの $K_{\mathrm{fl}}$ の平均值は，その他の丸 ワッシャーの辺長比の平均值と比較して約1.2倍高 い值となり，標準偏差も全供試体の中でも最も高い 
Table 1(b). Experimental values of $K_{\mathrm{fl}}, K_{\mathrm{te}}$ and $K_{\mathrm{pe}}$ of Circular washers.

\begin{tabular}{|c|c|c|c|c|c|c|c|c|}
\hline \multirow{2}{*}{ Metal washer } & Diameter & Thickness & \multirow{2}{*}{$\beta$} & & \multirow{2}{*}{$K_{\mathrm{f} 1}$} & $F_{\mathrm{y}}$ & $K_{\mathrm{te}}$ & $K_{\mathrm{pe}}$ \\
\hline & $\mathrm{mm}$ & $\mathrm{mm}$ & & & & $\mathrm{kN}$ & $\mathrm{N} / \mathrm{deg}$ & $\mathrm{N} / \mathrm{deg}$ \\
\hline \multirow{24}{*}{ Circular washer } & \multirow{4}{*}{30} & \multirow{4}{*}{1.6} & \multirow{4}{*}{18.8} & Max. & 0.384 & 4.25 & 11191 & 1193 \\
\hline & & & & Min. & 0.200 & 2.90 & 4773 & 617 \\
\hline & & & & Avg. & 0.255 & 3.39 & 7930 & 933 \\
\hline & & & & Std. & 0.072 & 0.53 & 2534 & 208 \\
\hline & \multirow{4}{*}{30} & \multirow{4}{*}{2.3} & \multirow{4}{*}{13.0} & Max. & 0.210 & 4.03 & 12302 & 1131 \\
\hline & & & & Min. & 0.177 & 2.59 & 5369 & 432 \\
\hline & & & & Avg. & 0.193 & 3.22 & 8057 & 898 \\
\hline & & & & Std. & 0.014 & 0.47 & 2513 & 269 \\
\hline & \multirow{4}{*}{32} & \multirow{4}{*}{2.0} & \multirow{4}{*}{16.0} & Max. & 0.220 & 4.55 & 10759 & 1522 \\
\hline & & & & Min. & 0.183 & 3.44 & 6377 & 411 \\
\hline & & & & Avg. & 0.200 & 3.97 & 8897 & 939 \\
\hline & & & & Std. & 0.012 & 0.46 & 1835 & 411 \\
\hline & \multirow{4}{*}{32} & \multirow{4}{*}{3.2} & \multirow{4}{*}{10.0} & Max. & 0.250 & 4.32 & 14853 & 1502 \\
\hline & & & & Min. & 0.191 & 3.24 & 7611 & 720 \\
\hline & & & & Avg. & 0.215 & 3.75 & 11369 & 1203 \\
\hline & & & & Std. & 0.023 & 0.45 & 3093 & 280 \\
\hline & \multirow{4}{*}{35} & \multirow{4}{*}{3.2} & \multirow{4}{*}{10.9} & Max. & 0.223 & 5.85 & 17136 & 1646 \\
\hline & & & & Min. & 0.194 & 3.35 & 7714 & 535 \\
\hline & & & & Avg. & 0.212 & 4.56 & 11866 & 1015 \\
\hline & & & & Std. & 0.011 & 1.10 & 4018 & 398 \\
\hline & \multirow{4}{*}{35} & \multirow{4}{*}{4.5} & \multirow{4}{*}{7.8} & Max. & 0.209 & 5.77 & 18741 & 1378 \\
\hline & & & & Min. & 0.180 & 3.14 & 10368 & 658 \\
\hline & & & & Avg. & 0.195 & 4.53 & 13046 & 1145 \\
\hline & & & & Std. & 0.011 & 0.98 & 3120 & 256 \\
\hline \multirow{4}{*}{ All specimen } & & & & Max. & 0.384 & & & \\
\hline & & & & Min. & 0.177 & & & \\
\hline & & & & Avg. & 0.212 & & & \\
\hline & & & & Std. & 0.037 & & & \\
\hline
\end{tabular}

Notes: $\beta$ : diameter / thickness ratio, $K_{\mathrm{f} 1}$ : torque coefficient, $F_{\mathrm{y}}$ : yield clamp force, $K_{\mathrm{te}}$ : elastic tightening stiffness, $K_{\text {pe }}$ : plastic tightening stiffness, Max. : maximum, Min. : minimum, Avg.: average, Std.: standard deviation.

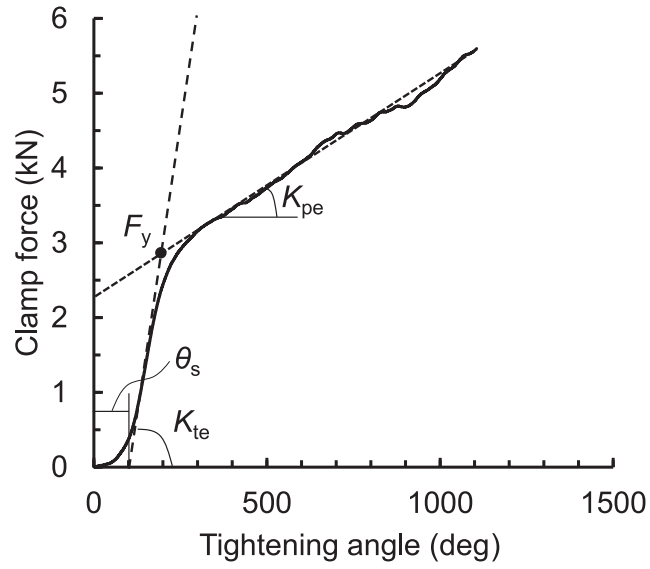

Fig. 6. Extraction of property value in relationship between clamp force and tightening angle.

Notes : $K_{\mathrm{te}}$ : elastic tightening stiffness, $\theta_{\mathrm{s}}$ : initial slip tightening angle, $F_{y}$ : yield clamp force, $K_{\text {pe }}$ : plastic tightening stiffness.

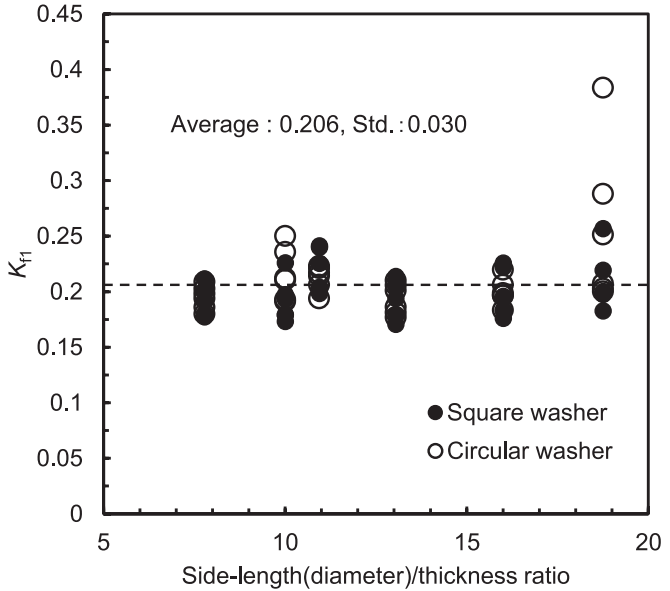

Fig. 7. Relationship between torque coefficient $K_{\mathrm{f} 1}$ and side-length (diameter) / thickness ratio.

Note: Std. : standard deviation. 
0.072 となった。ここで, 辺長比と締付け弾性剛性 $K_{\mathrm{te}}(\mathrm{N} / \mathrm{deg})$ の関係を Fig. 8(a)，（b)に示す。Fig. 8 によれば, 辺長比の増大に伴い, $K_{\mathrm{te}}$ は角ワッシャー, 丸ワッシャー共に減少傾向にあることがわかる。ま た, Fig. 9 に実験後の角ワッシャーの変形状況およ び木材のめり込み状況を示すが, 辺長比 18.8 , 13.0，16.0は曲げ変形が明確に確認できると共に全 ての辺長比で木材のめり込み痕が確認できる。これ らのことより, 辺長比が大きくなるにつれて, 角ワ ッシャー, 丸ワッシャー共に締付け弾性剛性 $K_{\mathrm{te}}$ は 低下するものの, 辺長比7.8から16.0まではトルク係 数 $K_{\mathrm{f} 1}$ に影響を与えないが, 最大辺長比18.8の場合

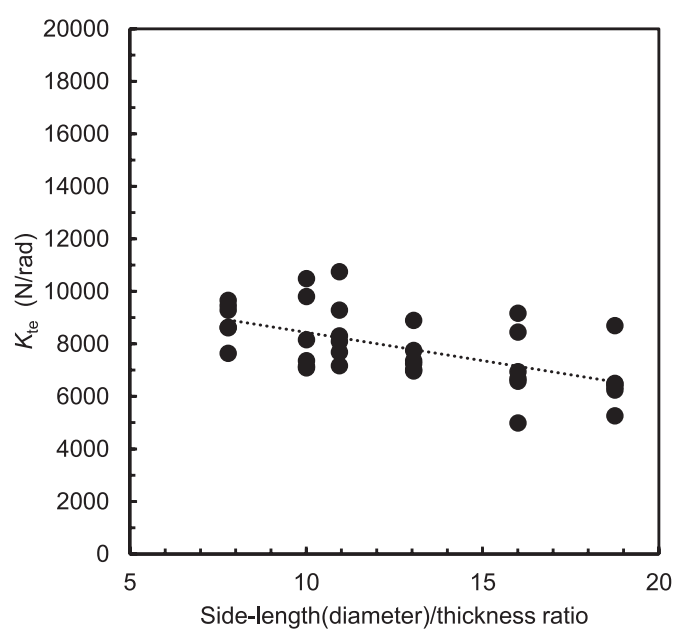

(a) Square washer

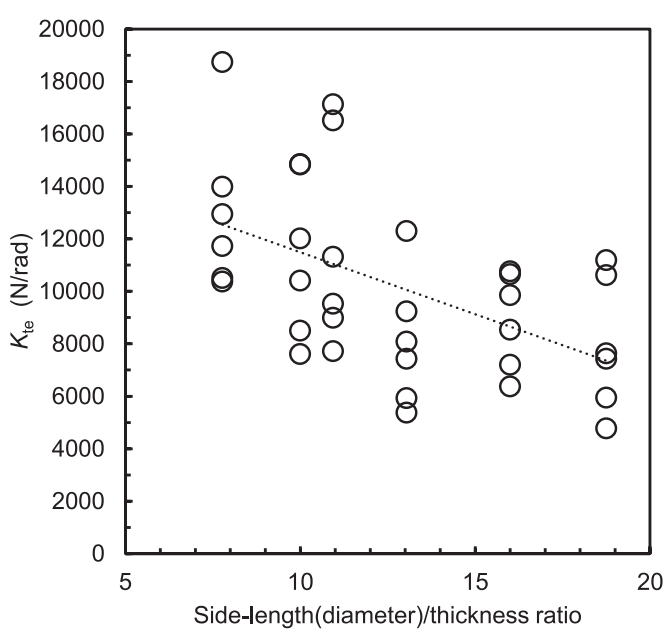

(b) Circular washer

Fig. 8. Relationship between $K_{\text {te }}$ and side-length (diameter) / thickness ratio.

Notes : $K_{\text {te }}$ : elastic tightening stiffness.
は, ワッシャーの形状がトルク係数 $K_{\mathrm{f} 1}$ に影響を与 えるとわかった。辺長比18.8の丸ワッシャーの $K_{\mathrm{f} 1}$ がその他の辺長比と比較してばらつくのは, ナ ットとワッシャーの接触状態, つまり座面の摩擦係 数 $\mu_{\mathrm{b}}$ が影響しているものと推察される。そこで, $\mu_{\mathrm{b}}$ およびねじ面の摩擦係数 $\mu_{\mathrm{th}}$ を以下の方法で算出 した。

$\mu_{\text {th }}$ は, 以下の (16) 式 ${ }^{16)} に よ り$ 表される。

$\mu_{\text {th }}=\frac{\frac{T_{\text {th }}}{F_{\mathrm{f}}}-\frac{P}{2 \pi}}{0.577 d_{2}} \quad \cdot \cdot(16)$

ここで， $T_{\mathrm{th}}$ は，実験より計測されるねじ部トルク である $(\mathrm{Nm})$ 。 $d_{2}$ はねじの有効径の基準寸法（こ こでは JIS B 1083 ${ }^{15)}$ に記載の $10.863 \mathrm{~mm}$ ）である。 $\mu_{\mathrm{b}}$ は, 以下の (17)式16)により表される。

$\mu_{\mathrm{b}}=\frac{T_{\mathrm{b}}}{0.5 D_{\mathrm{b}} F_{\mathrm{f}}} \quad \cdot \cdot(17)$

$T_{\mathrm{b}}$ は座面トルクであり $(\mathrm{Nm})$, 以下の $(18)$ 式 ${ }^{16)} に$ より表される。

$T_{\mathrm{b}}=T_{\mathrm{f}}-T_{\mathrm{th}} \quad \cdots \cdot(18)$

$D_{\mathrm{b}}$ は再掲するが, 以下の (19) 式 ${ }^{16)}$ により表される。

$D_{\mathrm{b}}=\frac{D_{0}+d_{\mathrm{h}}}{2} \quad \cdots$.

$D_{0}$ はナット座面の外径 $(18.7 \mathrm{~mm}), d_{\mathrm{h}}$ はワッシャ 一のボルト穴径 $(13.5 \mathrm{~mm})$ である。

このような方法で， $\mu_{\mathrm{th}}, \mu_{\mathrm{b}}$ を実験結果から算出 した結果一覧を Table 2(a)，（b)に示す。ここで, （16），(17)式の $T_{\mathrm{th}} / F_{\mathrm{f}}$ および $T_{\mathrm{b}} / F_{\mathrm{f}}$ は, 前述し た $K_{\mathrm{te}}, K_{\mathrm{f} 1}$ と同様の算出方法で, 最小二乗法によっ て算出した。これによれば, 辺長比18.8の丸ワッシ ヤーについて, $\mu_{\mathrm{b}}$ が全供試体の中でも最も高い值 0.428 を示し, 標準偏差も最も大きい 0.106 となりば らつきも大きい。したがって, 辺長比18.8の丸ワッ シャーについては， $\mu_{\mathrm{b}}$ が影響し， $K_{\mathrm{f} 1}$ が他の辺長比 と比較してばらついたと理解される。

また, $F_{\mathrm{y}} d$ の值はワッシャーの辺長比によって異

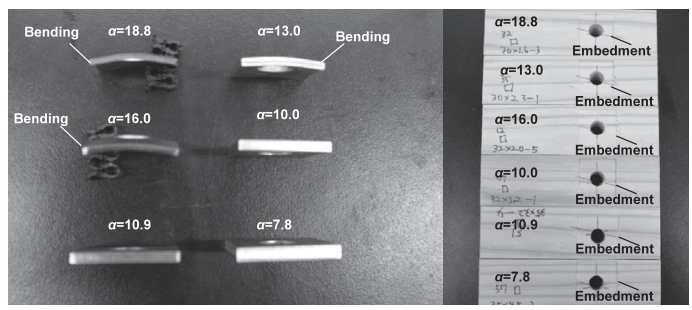

Fig. 9. Typical failures of timber and square washer after tightening test.

Notes : $\alpha$ is side-length/thickness ratio of metal washer. 
Table 2(a). Experimental values of $\mu_{\mathrm{th}}, \mu_{\mathrm{b}}$ of square washers.

\begin{tabular}{|c|c|c|c|c|c|c|}
\hline \multirow{2}{*}{ Metal washer } & Side-length & Thickness & \multirow{2}{*}{$\alpha$} & & \multirow[b]{2}{*}{$\mu_{\text {th }}$} & \multirow[b]{2}{*}{$\mu_{\mathrm{b}}$} \\
\hline & $\mathrm{mm}$ & $\mathrm{mm}$ & & & & \\
\hline \multirow{24}{*}{ Square washer } & \multirow{4}{*}{30} & \multirow{4}{*}{1.6} & \multirow{4}{*}{18.8} & Max. & 0.150 & 0.238 \\
\hline & & & & Min. & 0.088 & 0.107 \\
\hline & & & & Avg. & 0.126 & 0.168 \\
\hline & & & & Std. & 0.024 & 0.045 \\
\hline & \multirow{4}{*}{30} & \multirow{4}{*}{2.3} & \multirow{4}{*}{13.0} & Max. & 0.178 & 0.171 \\
\hline & & & & Min. & 0.108 & 0.129 \\
\hline & & & & Avg. & 0.136 & 0.151 \\
\hline & & & & Std. & 0.023 & 0.017 \\
\hline & \multirow{4}{*}{32} & \multirow{4}{*}{2.0} & \multirow{4}{*}{16.0} & Max. & 0.147 & 0.218 \\
\hline & & & & Min. & 0.029 & 0.143 \\
\hline & & & & Avg. & 0.097 & 0.184 \\
\hline & & & & Std. & 0.038 & 0.033 \\
\hline & \multirow{4}{*}{32} & \multirow{4}{*}{3.2} & \multirow{4}{*}{10.0} & Max. & 0.140 & 0.208 \\
\hline & & & & Min. & 0.114 & 0.092 \\
\hline & & & & Avg. & 0.127 & 0.138 \\
\hline & & & & Std. & 0.010 & 0.042 \\
\hline & \multirow{4}{*}{35} & \multirow{4}{*}{3.2} & \multirow{4}{*}{10.9} & Max. & 0.153 & 0.230 \\
\hline & & & & Min. & 0.120 & 0.155 \\
\hline & & & & Avg. & 0.135 & 0.186 \\
\hline & & & & Std. & 0.014 & 0.027 \\
\hline & \multirow{4}{*}{35} & \multirow{4}{*}{4.5} & \multirow{4}{*}{7.8} & Max. & 0.150 & 0.185 \\
\hline & & & & Min. & 0.109 & 0.138 \\
\hline & & & & Avg. & 0.124 & 0.157 \\
\hline & & & & Std. & 0.014 & 0.019 \\
\hline \multirow{4}{*}{ All specimen } & & & & Max. & 0.178 & 0.238 \\
\hline & & & & Min. & 0.029 & 0.092 \\
\hline & & & & Avg. & 0.124 & 0.164 \\
\hline & & & & Std. & 0.025 & 0.035 \\
\hline
\end{tabular}

Notes : $\alpha$ : side-length / thickness ratio, $\mu_{\mathrm{th}}$ : coefficient of friction between threads, $\mu_{\mathrm{b}}$ : coefficient of friction between bearing surfaces, Max. : maximum, Min. : minimum, Avg. : average, Std. : standard deviation.

なることがFig. 5(a)，(b)よりわかる。辺長比と $F_{\mathrm{y}} d$ との関係を Fig. 10(a)，(b)に示す。これによ れば, 辺長比の増大に伴い, $F_{\mathrm{y}} d$ は, 丸ワッシャー はややばらつきが大きいが，減少傾向にあることが わかる。この傾向は, ワッシャーのめり込み実験を 行った既報 ${ }^{14)}$ で確認された傾向と同様であった。

以上のことから，辺長比18.8の丸ワッシャーを除 いて, ワッシャーの辺長比 7.8 から16.0の範囲および 形状は弾性範囲のトルク係数 $K_{\mathrm{f} 1}$ に影響を及ぼさな いことがわかった。しかし，辺長比18.8，13.0，16.0 は明確に曲げ変形が確認されていることから，これ らの辺長比を持つワッシャーを用いて本研究の目的 である塑性域締付け管理することは実用面を考慮す ると現実的ではないと考えられる。そこで，次節の 塑性域挙動の考察については, 辺長比18.8, 13.0, 16.0 は本提案算定法の適用範囲外とし, 辺長比 10.0，10.9，7.8について考察を進める。

\subsection{2 塑性域締付け挙動に及ぼす影響}

まず, Fig. 5(a)，(b)を見ると, $F_{\mathrm{y}} d$ を越えた後は, 辺長比, 形状毎に塑性域トルク係数 $K_{\mathrm{f} 2}$ は $K_{\mathrm{f} 1}$ とは 異なるように見える。そこで, 塑性域トルク係数 $K_{\mathrm{f} 2}$ について, $F_{\mathrm{y}} d$ からめり込み量 $2 \mathrm{~mm}$ までとし

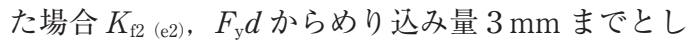

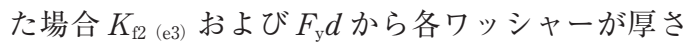
分めり込んだと想定した時までの勾配 $K_{\mathrm{f} 2 \text { (ae) }}$ とし て求めた。勾配は, 最小二乗法によって求めること とする。なお, Fig. 5(a), (b)の縦破線は各ワッシ ヤー厚さ分めり込んだと想定した時の締付け軸力 $F_{\mathrm{ae}} d$ を示している。ここで, 各めり达み量時の締付 け軸力は次の方法で求めた。例えば, $t \mathrm{~mm}$ 木材に めり込んだ時の回転角 $\theta$ は,

$\theta=360 \frac{t}{P} \quad \cdot \cdot(20)$

ここで $P$ はねじピッチ $(1.75 \mathrm{~mm})$ である。この $\theta$ 
Table 2(b). Experimental values of $\mu_{\mathrm{th}}, \mu_{\mathrm{b}}$ of Circular washers.

\begin{tabular}{|c|c|c|c|c|c|c|}
\hline \multirow{2}{*}{ Metal washer } & Diameter & Thickness & \multirow{2}{*}{$\beta$} & & \multirow{2}{*}{$\mu_{\text {th }}$} & \multirow{2}{*}{$\mu_{\mathrm{b}}$} \\
\hline & $\mathrm{mm}$ & $\mathrm{mm}$ & & & & \\
\hline \multirow{24}{*}{ Circular washer } & \multirow{4}{*}{30} & \multirow{4}{*}{1.6} & \multirow{4}{*}{18.8} & Max. & 0.155 & 0.428 \\
\hline & & & & Min. & 0.124 & 0.155 \\
\hline & & & & Avg. & 0.141 & 0.236 \\
\hline & & & & Std. & 0.012 & 0.106 \\
\hline & \multirow{4}{*}{30} & \multirow{4}{*}{2.3} & \multirow{4}{*}{13.0} & Max. & 0.160 & 0.197 \\
\hline & & & & Min. & 0.079 & 0.104 \\
\hline & & & & Avg. & 0.120 & 0.160 \\
\hline & & & & Std. & 0.028 & 0.032 \\
\hline & \multirow{4}{*}{32} & \multirow{4}{*}{2.0} & \multirow{4}{*}{16.0} & Max. & 0.177 & 0.179 \\
\hline & & & & Min. & 0.116 & 0.134 \\
\hline & & & & Avg. & 0.148 & 0.148 \\
\hline & & & & Std. & 0.022 & 0.021 \\
\hline & \multirow{4}{*}{32} & \multirow{4}{*}{3.2} & \multirow{4}{*}{10.0} & Max. & 0.167 & 0.217 \\
\hline & & & & Min. & 0.122 & 0.131 \\
\hline & & & & Avg. & 0.142 & 0.176 \\
\hline & & & & Std. & 0.017 & 0.032 \\
\hline & \multirow{4}{*}{35} & \multirow{4}{*}{3.2} & \multirow{4}{*}{10.9} & Max. & 0.159 & 0.212 \\
\hline & & & & Min. & 0.107 & 0.153 \\
\hline & & & & Avg. & 0.135 & 0.177 \\
\hline & & & & Std. & 0.020 & 0.020 \\
\hline & \multirow{4}{*}{35} & \multirow{4}{*}{4.5} & \multirow{4}{*}{7.8} & Max. & 0.153 & 0.166 \\
\hline & & & & Min. & 0.118 & 0.134 \\
\hline & & & & Avg. & 0.139 & 0.148 \\
\hline & & & & Std. & 0.014 & 0.011 \\
\hline \multirow{4}{*}{ All specimen } & & & & Max. & 0.177 & 0.428 \\
\hline & & & & Min. & 0.079 & 0.104 \\
\hline & & & & Avg. & 0.138 & 0.174 \\
\hline & & & & Std. & 0.020 & 0.054 \\
\hline
\end{tabular}

Notes: $\beta$ : diameter / thickness ratio, $\mu_{\mathrm{th}}$ : coefficient of friction between threads, $\mu_{\mathrm{b}}$ : coefficient of friction between bearing surfaces, Max. : maximum, Min. : minimum, Avg. : average, Std. : standard deviation.

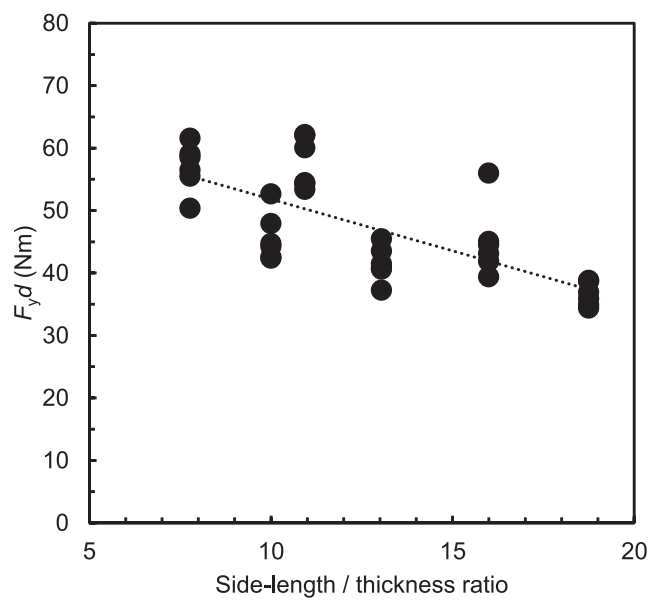

(a) Square washer

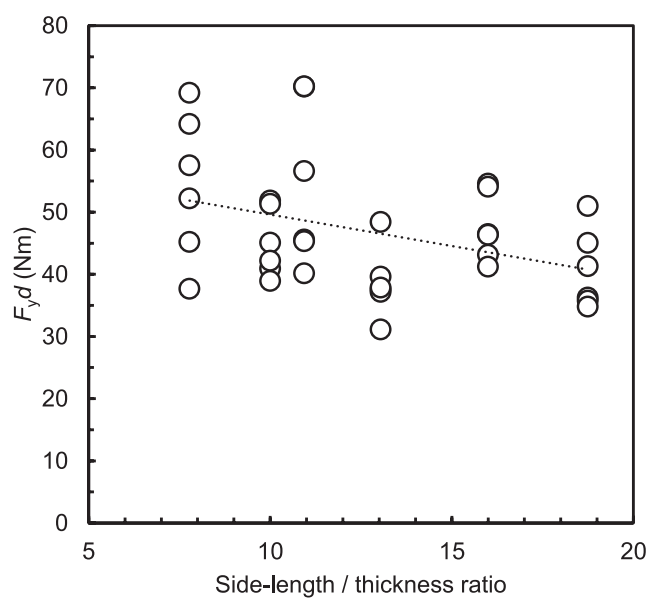

(b) Circular washer

Fig. 10. Relationship between $F_{\mathrm{y}}$ and side-length (diameter) / thickness ratio. Notes : $F_{\mathrm{y}}$ : yield clamp force, $d$ : bolt diameter. 
Table 3(a). Experimental values of $K_{\mathrm{f} 1}, K_{\mathrm{f} 2}, \gamma_{\max }$ and $\gamma_{\min }$ of square washers.

\begin{tabular}{|c|c|c|c|c|c|c|c|c|c|c|c|c|c|c|c|}
\hline \multirow{2}{*}{$\begin{array}{c}\text { Metal } \\
\text { washer }\end{array}$} & \multirow[b]{2}{*}{$\alpha$} & & \multirow{2}{*}{$K_{\mathrm{f} 1}$} & \multicolumn{4}{|c|}{$\begin{array}{l}2 \mathrm{~mm} \text { embedment } \\
\text { into timber }\end{array}$} & \multicolumn{4}{|c|}{$\begin{array}{l}3 \mathrm{~mm} \text { embedment } \\
\text { into timber }\end{array}$} & \multicolumn{4}{|c|}{$\begin{array}{l}\text { Washer thickness embedment } \\
\text { into timber }\end{array}$} \\
\hline & & & & $K_{\mathrm{f} 2(\mathrm{e} 2)}$ & $\begin{array}{l}K_{\mathrm{f} 2(\mathrm{e} 2)} \\
/ K_{\mathrm{f} 1}\end{array}$ & $\gamma_{\max }$ & $\gamma_{\min }$ & $K_{\mathrm{f} 2(\mathrm{e} 3)}$ & $\begin{array}{c}K_{\mathrm{f} 2(\mathrm{e})} \\
/ K_{\mathrm{f} 1}\end{array}$ & $\gamma_{\text {max }}$ & $\gamma_{\min }$ & $K_{\mathrm{f} 2 \text { (aе) }}$ & $\begin{array}{l}K_{\mathrm{f} 2(\mathrm{ae})} \\
/ K_{\mathrm{f} 1}\end{array}$ & $\gamma_{\max }$ & $\gamma_{\min }$ \\
\hline \multirow{12}{*}{$\begin{array}{l}\text { Square } \\
\text { washer }\end{array}$} & \multirow{4}{*}{10.0} & Max. & 0.226 & 0.321 & 1.63 & \multirow{4}{*}{1.42} & \multirow{4}{*}{0.64} & 0.290 & 1.47 & \multirow{4}{*}{1.28} & \multirow{4}{*}{1.03} & 0.303 & 1.53 & \multirow{4}{*}{1.34} & \multirow{4}{*}{1.11} \\
\hline & & Min. & 0.173 & 0.111 & 0.58 & & & 0.178 & 0.99 & & & 0.192 & 1.00 & & \\
\hline & & Avg. & 0.191 & 0.186 & 0.96 & & & 0.218 & 1.14 & & & 0.227 & 1.19 & & \\
\hline & & Std. & 0.019 & 0.079 & 0.37 & & & 0.040 & 0.18 & & & 0.041 & 0.19 & & \\
\hline & \multirow{4}{*}{10.9} & Max. & 0.241 & 0.323 & 1.34 & \multirow{4}{*}{1.34} & \multirow{4}{*}{0.72} & 0.498 & 2.08 & \multirow{4}{*}{2.07} & \multirow{4}{*}{1.25} & 0.513 & 2.14 & \multirow{4}{*}{2.13} & \multirow{4}{*}{1.30} \\
\hline & & Min. & 0.198 & 0.144 & 0.72 & & & 0.248 & 1.13 & & & 0.258 & 1.16 & & \\
\hline & & Avg. & 0.219 & 0.219 & 0.98 & & & 0.318 & 1.44 & & & 0.328 & 1.49 & & \\
\hline & & Std. & 0.019 & 0.082 & 0.28 & & & 0.093 & 0.34 & & & 0.095 & 0.35 & & \\
\hline & \multirow{4}{*}{7.8} & Max. & 0.212 & 0.236 & 1.22 & \multirow{4}{*}{1.12} & \multirow{4}{*}{0.90} & 0.272 & 1.36 & \multirow{4}{*}{1.29} & \multirow{4}{*}{0.98} & 0.373 & 1.87 & \multirow{4}{*}{1.76} & \multirow{4}{*}{1.32} \\
\hline & & Min. & 0.177 & 0.159 & 0.88 & & & 0.175 & 0.93 & & & 0.234 & 1.10 & & \\
\hline & & Avg. & 0.194 & 0.195 & 1.00 & & & 0.230 & 1.19 & & & 0.290 & 1.51 & & \\
\hline & & Std. & 0.013 & 0.034 & 0.14 & & & 0.043 & 0.18 & & & 0.054 & 0.29 & & \\
\hline
\end{tabular}

Notes : $\alpha$ : side-length / thickness ratio, $K_{\mathrm{f} 1}$ : torque coefficient, $K_{\mathrm{f} 2(\mathrm{e} 2)}$ : plastic torque coefficient on $2 \mathrm{~mm}$ embedment into timber of metal washer, $K_{\mathrm{f} 2(\mathrm{e} 3)}$ : plastic torque coefficient on $3 \mathrm{~mm}$ embedment into timber of metal washer, $K_{\mathrm{f} 2(\mathrm{ae})}$ : plastic torque coefficient on washer thickness embedment into timber, $\gamma_{\max }$ : ratio of maximum plastic torque coefficient to maximum torque coefficient $\left(=K_{\mathrm{f} 2 \max } / K_{\mathrm{flmax}}\right), \gamma_{\min }$ : ratio of minimum plastic torque coefficient to minimum torque coefficient $\left(=K_{\mathrm{f} 2 \min } / K_{\mathrm{flmin}}\right)$, Max. : maximum, Min. : minimum, Avg. : average, Std. : standard deviation.

Table 3(b). Experimental values of $K_{\mathrm{f} 1}, K_{\mathrm{f} 2}, \gamma_{\max }$ and $\gamma_{\min }$ of circular washers.

\begin{tabular}{|c|c|c|c|c|c|c|c|c|c|c|c|c|c|c|c|}
\hline \multirow{2}{*}{$\begin{array}{c}\text { Metal } \\
\text { washer }\end{array}$} & \multirow{2}{*}{$\beta$} & & \multirow{2}{*}{$K_{\mathrm{f} 1}$} & \multicolumn{4}{|c|}{$\begin{array}{l}2 \mathrm{~mm} \text { embedment } \\
\text { into timber }\end{array}$} & \multicolumn{4}{|c|}{$\begin{array}{l}3 \mathrm{~mm} \text { embedment } \\
\text { into timber }\end{array}$} & \multicolumn{4}{|c|}{$\begin{array}{l}\text { Washer thickness embedment } \\
\text { into timber }\end{array}$} \\
\hline & & & & $K_{\mathrm{f} 2(\mathrm{e} 2)}$ & $\begin{array}{l}K_{\mathrm{f} 2(22)} \\
/ K_{\mathrm{f} 1}\end{array}$ & $\gamma_{\text {max }}$ & $\gamma_{\text {min }}$ & $K_{\mathrm{f} 2(\mathrm{e} 3)}$ & $\begin{array}{l}K_{\mathrm{f} 2(\mathrm{e} 3)} \\
/ K_{\mathrm{f} 1}\end{array}$ & $\gamma_{\text {max }}$ & $\gamma_{\text {min }}$ & $K_{\mathrm{f2}(\text { ae })}$ & $\begin{array}{r}K_{\mathrm{f} 2(\mathrm{ae}} \\
/ K_{\mathrm{fl}}\end{array}$ & $\gamma_{\text {max }}$ & $\gamma_{\min }$ \\
\hline \multirow{12}{*}{$\begin{array}{l}\text { Circular } \\
\text { washer }\end{array}$} & \multirow{4}{*}{10.0} & Max. & 0.250 & 0.334 & 1.57 & \multirow{4}{*}{1.33} & \multirow{4}{*}{1.02} & 0.356 & 1.86 & \multirow{4}{*}{1.42} & \multirow{4}{*}{1.28} & 0.364 & 1.91 & \multirow{4}{*}{1.46} & \multirow{4}{*}{1.28} \\
\hline & & Min. & 0.191 & 0.195 & 0.90 & & & 0.244 & 1.16 & & & 0.244 & 1.16 & & \\
\hline & & Avg. & 0.215 & 0.258 & 1.22 & & & 0.304 & 1.43 & & & 0.312 & 1.47 & & \\
\hline & & Std. & 0.023 & 0.048 & 0.29 & & & 0.038 & 0.29 & & & 0.041 & 0.31 & & \\
\hline & \multirow{4}{*}{10.9} & Max. & 0.223 & 0.254 & 1.23 & \multirow{4}{*}{1.14} & \multirow{4}{*}{0.90} & 0.333 & 1.54 & \multirow{4}{*}{1.50} & \multirow{4}{*}{1.05} & 0.346 & 1.60 & \multirow{4}{*}{1.55} & \multirow{4}{*}{1.06} \\
\hline & & Min. & 0.194 & 0.174 & 0.78 & & & 0.203 & 0.93 & & & 0.206 & 0.95 & & \\
\hline & & Avg. & 0.212 & 0.217 & 1.03 & & & 0.256 & 1.21 & & & 0.264 & 1.25 & & \\
\hline & & Std. & 0.011 & 0.028 & 0.18 & & & 0.051 & 0.24 & & & 0.055 & 0.26 & & \\
\hline & \multirow{4}{*}{7.8} & Max. & 0.209 & 0.222 & 1.17 & \multirow{4}{*}{1.07} & \multirow{4}{*}{0.90} & 0.277 & 1.38 & \multirow{4}{*}{1.33} & \multirow{4}{*}{1.11} & 0.428 & 2.11 & \multirow{4}{*}{2.05} & \multirow{4}{*}{1.51} \\
\hline & & Min. & 0.180 & 0.161 & 0.83 & & & 0.199 & 1.03 & & & 0.272 & 1.30 & & \\
\hline & & Avg. & 0.195 & 0.197 & 1.01 & & & 0.239 & 1.23 & & & 0.308 & 1.58 & & \\
\hline & & Std. & 0.011 & 0.027 & 0.13 & & & 0.027 & 0.13 & & & 0.059 & 0.28 & & \\
\hline
\end{tabular}

Notes: $\beta$ : diameter / thickness ratio, $K_{\mathrm{f} 1}$ : torque coefficient, $K_{\mathrm{f} 2(\mathrm{e} 2)}$ : plastic torque coefficient on $2 \mathrm{~mm}$ embedment into timber of metal washer, $K_{\mathrm{f} 2(\mathrm{e} 3)}$ : plastic torque coefficient on $3 \mathrm{~mm}$ embedment into timber of metal washer, $K_{\mathrm{f} 2(\mathrm{ae})}$ : plastic torque coefficient on washer thickness embedment into timber, $\gamma_{\max }$ : ratio of maximum plastic torque coefficient to maximum torque coefficient $\left(=K_{\mathrm{f} 2 \max } / K_{\mathrm{flmax}}\right), \gamma_{\min }$ : ratio of minimum plastic torque coefficient to minimum torque coefficient $\left(=K_{\mathrm{f} 2 \min } / K_{\mathrm{flmin}}\right)$, Max. : maximum, Min. : minimum, Avg.: average, Std. : standard deviation.

に Fig. 6 に示したようにスリップ回転角 $\theta_{\mathrm{s}}$ を加え た值を厚さ $t \mathrm{~mm}$ のワッシャーが全てめり込んだも のとし，その時の回転角から各実験結果より各締付 け軸力を抽出した。ここで厳密には, ボルトが締付 けによって伸びて，ねじピッチが変化しているが, 実験より計測された全72体の $F_{\text {ae }}$ の最大值 $(10 \mathrm{kN})$
から最大のボルトの伸び率を概算（ボルト首下長, ボルトのヤング係数, ボルト有効断面積から換算) すると $0.06 \%$ 程度であったことから，ねじピッチは 保持されているとみなした。

Table 3 に抽出した各ワッシャーの $K_{\mathrm{f} 1}$, 各 $K_{\mathrm{f} 2}$ お よび 2. で定義した $\gamma_{\max }, \gamma_{\min }$ を示す。ここで, 表に 
は併せて供試体個々の $K_{\mathrm{f} 2} / K_{\mathrm{f} 1}$ の結果も示した。 これによれば，まず角・丸ワッシャーの辺長比毎に $\gamma_{\max }, \gamma_{\min }$ を見てみると, ワッシャーのめり込みが 進展するに伴い， $\gamma_{\text {max }} ， \gamma_{\text {min }}$ はそれぞれ変化し, 辺 長比10.0の角ワッシャーを除いて増加傾向にあるこ とがわかる。 $\gamma_{\text {max }}$ は, 最小 1.07 か最大 $2.13, \gamma_{\text {min }}$ は最小 0.64 から最大 1.51 となり変動が大きい。この ように変化するのは，座面もしくはねじ部の摩擦係 数が変動していたためと推測される。そこで, 実験 後に各ワッシャーの表面を観察したところ, Fig. 11 のように円形の削り痕が全ての供試体で確認され た。つまり,ナットを締付けてワッシャーのめり込 みが進展するに伴い，ナット座面が刻々とワッシャ 一表面を削ることにより摩擦係数が変動するためで あると推察される。一方，ねじ部の状況を観察した が, 目視で判断する限り, ワッシャーの削り痕のよ うに明確な破壞等は確認されなかった。また， $K_{\mathrm{f} 2}$ $/ K_{\mathrm{fl}}$ を見ると, $\gamma_{\max }, \gamma_{\min }$ と同様に, ワッシャー のめり込みが進展するに伴い, 最大, 最小は増加傾 向にあることがわかる。ここで， $\gamma_{\max }, \gamma_{\text {min }}$ および $K_{\mathrm{f} 2} / K_{\mathrm{f} 1}$ の Max. と Min. をそれぞれ対比させ両者 の関係を見てみると, 例えば, 最大 $K_{\mathrm{f} 2} / K_{\mathrm{f} 1}$ は, 角ワッシャー10.9の $K_{\mathrm{f} 2 \text { (ae) }} / K_{\mathrm{fl}}$ で2.14, 最大 $\gamma_{\text {max }}$ は 同様に角ワッシャー10.9の $K_{\mathrm{f} 2 \text { (аe) }}$ の場合で2.13, 最 小 $K_{\mathrm{f} 2} / K_{\mathrm{f} 1}$ は角ワッシャー10.0の $K_{\mathrm{f} 2(\mathrm{e} 2)} / K_{\mathrm{f} 1}$ で 0.58 , 最小 $\gamma_{\min }$ は同様に $K_{\mathrm{f} 2 \text { (e2) }}$ の場合で 0.64 となり, ほぼ同值であった。

ところで，めり込みが進展するに伴い $\gamma_{\max }, \gamma_{\text {min }}$ が変化しているので, 締付けトルクと締付け軸力の 関係は，厳密にはバイリニアとは異なる関係となっ ている。つまり，2.で示した算定法で厳密に計算す るとなると, ワッシャーのめり込み変位量を基準に して $\gamma_{\max }, \gamma_{\text {min }}$ を設定する計算法となると考えられ る。例えば，ワッシャー厚さまでめり込ませること を指標とするならば, $\gamma_{\max }, \gamma_{\text {min }}$ は $F_{\mathrm{y}} d$ から $F_{\text {ae }} d$ までの勾配すなわち $K_{\mathrm{f} 2 \text { (ae) }}$ から算出した值を設定

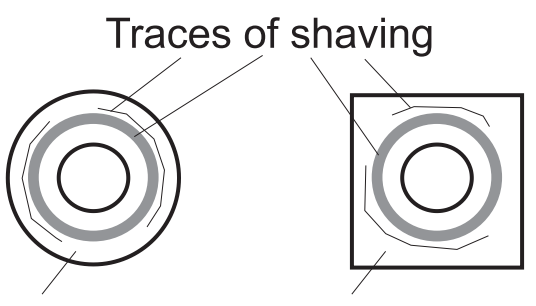

\section{Circular washer Square washer}

Fig. 11. Typical failures of square washer and circular washer after tightening test.
し計算するという手順になる。このように，めり込 みの進行に着目すると, 厳密に計算するにはめり込 み変位量を変数として $\gamma_{\text {max }}, \gamma_{\text {min }}$ を設定しなくては ならないが, めり达み変位量で軸力を管理する手法 は実用面を考慮すると難しさがあると考えられる。

\section{$4.2 \gamma_{\max }, \gamma_{\min }$ の設定とトルクレンチを用いた締 付け検証実験}

前述したように, $\gamma_{\text {max }}, \gamma_{\text {min }}$ はめり込みの程度に よって異なるため, 設定には細心の注意が必要であ るが，2.でも述べたように，実用面では $T_{\mathrm{A}}$ で締付 けた場合に締付け軸力が $F_{\min }$ と $F_{\text {max }}$ の範囲内に収 まることに加え, $F_{\min }$ を保証することが重要となる。 そこで, めり込み変位量を変数とした厳密な計算と 比べ精度は劣るかもしれないが, $\gamma_{\text {max }}, \gamma_{\text {min }}$, $K_{\mathrm{fl} \max }, K_{\mathrm{fl} \min }$ を次のように設定することを提案する。 2.の(10)，（12)式によれば， $\gamma_{\max }, K_{\mathrm{flmax}}$ が大きい ほど $F_{\max }, T_{\mathrm{f} 2 \min }$ は大きくなる。一方， $(10),(11)$ 式によれば, $\gamma_{\text {min }}, K_{\mathrm{flmin}}$ が小さいほど, $F_{\max }$ は大 きくなると共に $T_{\mathrm{f} 2 \max }$ は小さくなる。つまり，

$\gamma_{\max }, \gamma_{\min }, K_{\mathrm{fl} \max }, K_{\mathrm{fl} \min }$ をそれぞれ全供試体の中 の最大・最小として評価すれば, 設定 $F_{\min }$ と計算 $F_{\max }$ の差が大きくなるので, 締付け軸力をその範囲 内に収めることが可能となると考えられる。以上の ことから, Table 3, Fig.7 より辺長比10.0, 10.9, 7.8 の $K_{\mathrm{fl}}$ に有意差がなかったので, $K_{\mathrm{fl} \max }, K_{\mathrm{f} 1 \mathrm{~min}}$ はそ れぞれ辺長比10.0，10.9，7.8の全デー夕の最大, 最 小とし, $\gamma_{\max }, \gamma_{\min }$ はそれぞれ最大の2.13を2.1, 最 小の0.64を0.6として設定する。そこで, これらの各 係数を用いて, 2. で示した算定法より $T_{\mathrm{A}}$ を計算し, この $T_{\mathrm{A}}$ をトルクレンチにて与えた時に $F_{\max }, F_{\min }$ の範囲の軸力をどの程度捉えるのか, 辺長比 7.8 の

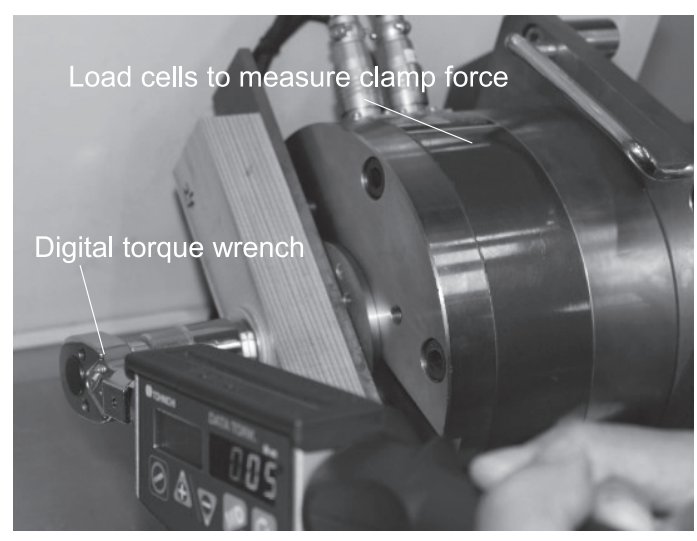

Fig. 12. Tightening test to measure clamp force using digital torque wrench. 
角ワッシャーおよび丸ワッシャーを用いて検証実験 を行った。実験時の様子を Fig. 12に, 計算結果お よび実験結果を Table 4 に示す。実験は, 本研究で 用いたねじ締付け試験機に，3.で示した供試体で余 った供試体を設置し，デジタルトルクレンチ最大容 量50 Nm（東日製作所 CEM50N3X12D）を用いナ ットを手動で締付け, 締付け軸力をロードセルから データロガーより抽出し, 設定トルクに達した時の 值を読み取った。供試体数は各 6 体とした。ここで 計算に用いた $F_{\min }$ は $6 \mathrm{kN}$ とした。 $F_{\mathrm{y}}$ は Table 1 よ り角・丸ワッシャーそれぞれ辺長比7.80平均值と した。また, トルクレンチによるトルクの誤差率 $m$ は, JIS B 4650

Table 4 によれば，角・丸ワッシャー共に実験值 の締付け軸力の Min. は $F_{\text {min }}$ 以上となっていると共 に, Max.は $F_{\max }$ を越えていなかった。しかし，実 験值の最大は, 計算 $F_{\text {max }}$ に対して約 2 倍の差が生 じていた。このように計測軸力と $F_{\text {max }}$ の差が大き くなるが，提案のように $\gamma_{\max }, \gamma_{\min }, K_{\mathrm{fl} \max }, K_{\mathrm{fl} \min }$ をそれぞれ最大・最小と評価することで, 締付け軸 力は少なくとも $F_{\min }$ 以上は捉えられるものと共に, $F_{\min }$ と $F_{\text {max }}$ の範囲内に収まるものと考えられる。

以上のことから， $\gamma_{\text {max }}$ を2.1， $\gamma_{\text {min }}$ を0.6として設 定し本提案算定法によって締付けトルク算定するこ とにより， $F_{\min }$ および $F_{\text {max }}$ の範囲内の塑性域締付 け軸力を得られることがわかった。しかし， $\gamma_{\text {max }}$ は, 最小 1.07 から最大 $2.13, \quad \gamma_{\min }$ は最小 0.64 から最大 1.51 と大きく変動している。ここで，2.の(10)，(11）, (12)式より， $\gamma_{\text {max }}, \gamma_{\text {min }}$ が1.0となる場合には, 締付 けトルクと締付け軸力の関係は, リニアモデルとな るので，非常に簡便となる。 $\gamma_{\max }, \gamma_{\min }$ が1.0の状態
とは, $K_{\mathrm{fl}}$ と $K_{\mathrm{f} 2}$ が等しいので, 弾性域の座面摩擦 やねじ部摩擦挙動が安定化したまま塑性域まで続く と考えられ，座面とねじ部の摩擦挙動を安定化させ ることで1.0の状態に近似できる可能性が考えられ る。具体的な方法としては，例えば，座面およびね じ部に適切な潤滑剤などを用いて座面とねじ部の摩 擦挙動を安定化させる方法が考えられる。この潤滑 剤などの有無がどのように $\gamma_{\text {max }}, \gamma_{\text {min }}$ に影響を与え るのかについては報を改めたい。

\section{5. 結 論}

木材のボルト接合において, 締付けトルクと締付 け軸力の関係をバイリニアモデルで表すことで，塑 性域締付け軸力を管理するための締付けトルク算定 法を提案した。そしてワッシャーの辺長比を7.8 (35 $\times \mathrm{t} 4.5 \mathrm{~mm})$ から $18.8(30 \times \mathrm{t} 1.6 \mathrm{~mm})$ の範囲でパ ラメータとした 12 種類のワッシャーを対象とし，木 材にスギを用いた締付け実験を行い, 辺長比がトル ク係数などにどのような影響を及ぼすのか把握する と共に, 提案算定法による計算值を検証した。本研 究の範囲内で得られた知見を以下に示す。

1. 辺長比 $18.8(30 \times \mathrm{t} 1.6 \mathrm{~mm})$ の丸ワッシャーを 除き, 弾性範囲内では, 辺長比はトルク係数に影響 を及ほささなことがわかった。

2. 辺長比 $18.8(30 \times \mathrm{t} 1.6 \mathrm{~mm}), 13.0(30 \times \mathrm{t} 2.3 \mathrm{~mm})$, $16.0(32 \times \mathrm{t} 2.0 \mathrm{~mm})$ のワッシャーについて, ワッ シャーの曲げ変形が確認された。

3. ワッシャーの辺長比の増大に伴い, 降伏締付け 軸力は低下傾向にあることがわかった。

4. 算定法にて新たに定義した $\gamma_{\max }, \gamma_{\min }$ は, 辺長 比10.0 $(32 \times \mathrm{t} 3.2 \mathrm{~mm}), 10.9(35 \times \mathrm{t} 3.2 \mathrm{~mm}), 7.8(35$

Table 4. Calculated values of plastic tightening torque and experimental results of plastic clamp force.

\begin{tabular}{|c|c|c|c|c|c|c|c|c|c|c|c|c|c|c|c|}
\hline \multirow{4}{*}{$\begin{array}{c}\text { Metal } \\
\text { washer }\end{array}$} & \multirow{4}{*}{$\alpha, \beta$} & \multicolumn{6}{|c|}{ Design variable } & \multirow{2}{*}{\multicolumn{4}{|c|}{ Calculated value }} & \multirow{2}{*}{\multicolumn{4}{|c|}{$\begin{array}{l}\text { Clamp force }(n=6) \\
\text { (Experimental values) }\end{array}$}} \\
\hline & & $F_{\min }$ & $F_{\mathrm{y}}$ & \multirow{3}{*}{$K_{\mathrm{flmax}}$} & \multirow{3}{*}{$K_{\mathrm{flmin}}$} & \multirow{3}{*}{$\gamma_{\max }$} & \multirow{3}{*}{$\gamma_{\min }$} & & & & & & & & \\
\hline & & \multirow{2}{*}[\mathrm{kN}]{} & \multirow{2}{*}[\mathrm{kN}]{} & & & & & $F_{\max }$ & $T_{\text {f2max }}$ & $T_{\mathrm{f} 2 \min }$ & $T_{\mathrm{A}}$ & Max. & Min. & Avg. & Std. \\
\hline & & & & & & & & {$[\mathrm{kN}]$} & {$[\mathrm{Nm}]$} & {$[\mathrm{Nm}]$} & {$[\mathrm{Nm}]$} & {$[\mathrm{kN}]$} & {$[\mathrm{kN}]$} & {$[\mathrm{kN}]$} & {$[\mathrm{kN}]$} \\
\hline $\begin{array}{l}\text { Square } \\
\text { washer }\end{array}$ & 7.8 & 6.00 & 4.75 & 0.250 & 0.173 & 2.10 & 0.60 & 14.95 & 22.57 & 22.13 & 22.35 & 8.00 & 6.85 & 7.27 & 0.40 \\
\hline $\begin{array}{l}\text { Circular } \\
\text { washer }\end{array}$ & 7.8 & 6.00 & 4.53 & 0.250 & 0.173 & 2.10 & 0.60 & 15.70 & 23.31 & 22.85 & 23.08 & 7.15 & 6.60 & 6.92 & 0.21 \\
\hline
\end{tabular}

Notes: $\alpha$ : side-length / thickness ratio of square washer, $\beta$ : diameter / thickness ratio of circular washer, $F_{\min }$ : target minimum plastic clamp force, $F_{\mathrm{y}}$ : yield clamp force, $K_{\mathrm{flmax}}$ : maximum torque coefficient, $K_{\mathrm{f} 1 \min }$ : minimum torque coefficient, $\gamma_{\max }$ : ratio of maximum plastic torque coefficient to maximum torque coefficient, $\gamma_{\min }$ : ratio of minimum plastic torque coefficient to minimum torque coefficient, $F_{\max }$ : target maximum plastic clamp force (calculated value), $T_{\mathrm{f} 2 \max }$ : calculated maximum plastic tightening torque, $T_{\mathrm{f} 2 \min }$ : calculated minimum plastic tightening torque, $T_{\mathrm{A}}$ : calculated plastic tightening torque, Max. : maximum, Min. : minimum, Avg. : average, Std. : standard deviation. 
×t $4.5 \mathrm{~mm}$ ）の条件において, ワッシャーのめり达 みが進展するに伴い変動し, 増加傾向にあることが わかった。

5. 辺長比 $10.0(32 \times \mathrm{t} 3.2 \mathrm{~mm}), 10.9(35 \times \mathrm{t} 3.2 \mathrm{~mm})$, $7.8(35 \times \mathrm{t} 4.5 \mathrm{~mm})$ の条件に扔いて, $\gamma_{\text {max }}$ を2.1, $\gamma_{\text {min }}$ を 0.6 として設定し本提案算定法によってトル ク算定することで, $F_{\text {min }}$ および $F_{\text {max }}$ の範囲内の塑 性域締付け軸力を得られることがトルクレンチを用 いた検証実験よりわかった。

以上のことから， ワッシャー辺長比 $10.0(32 \times \mathrm{t}$ $3.2 \mathrm{~mm}), 10.9(35 \times \mathrm{t} 3.2 \mathrm{~mm}), 7.8(35 \times \mathrm{t} 4.5 \mathrm{~mm})$ を持つスギ材ーボルト接合において本提案算定法で 締付けトルク算定することにより， $F_{\min }$ と $F_{\max }$ の 範囲内の塑性域締付け軸力は得られるものと考えら れる。しかし， $\gamma_{\max }, \gamma_{\min }$ のばらつきを小さくする 方法および辺長比が同じでもワッシャー寸法が変化 した場合に本算定法が適用可能かについても今後の 課題となる。

\section{謝辞}

本研究は, 平成 27 年度農林水産業・食品産業科学 技術研究推進事業「スギの圧縮と摩擦特性を活かし た高減衰耐力壁の開発 課題番号 : 27015A 研究代 表者: 若島嘉朗」の一部として行われたものです。 ここに記して感謝申し上げます。

\section{文献}

1）若島嘉朗：木造住宅用制振壁に関する取組と 課題. 生物資源 9(3),2-16 (2015).

2) 平井卓郎：鋼板サイドウェブを持つ木材 - ボ ルト接合部のせん断耐力に及ぼす摩擦抵抗の 影響. 木材学会誌 37 (6), 517-522 (1991).

3) Awaludin, A., Hirai, T., Hayashikawa, T., Sasaki, Y.: Load-carrying capacity of steelto-timber joints with a pretensioned bolt. $J$. Wood Sci. 54(5), 362-368 (2008).

4）松原独歩, 島田勝廣, 服部順昭：締付け軸力が 木材添え板ボルト接合部のせん断耐力に及ぼ す影響. 木材工業 68(9), 382-386 (2013).

5) Awaludin, A., Hirai, T., Hayashikawa, T., Sasaki, Y., Oikawa, A.: Effect of pretension in bolts on hysteretic responses of momentcarrying timber joints. J. Wood Sci. 54(2), 114-120 (2008).

6) Hirai, T., Meng, Q., Sawata, K., Koizumi, A.,
Sasaki, Y., Uematsu, T.: Some aspects of frictional resistance in timber constructions. Proceedings of World Conference on Timber Engineering, Miyazaki, Japan, 2008, pp. 140147.

7）孟 慶軍, 平井卓郎, 澤田 圭, 佐々木義久, 小 泉章夫, 植松武是 : 枠組壁工法における壁一床 接合部のせん断耐力に及ぼす摩擦力の影響. 木材学会誌 56(1), 48-54 (2010).

8）藤元嘉安, 雑賀伸浩, 又木義博 : 木質部材のボ ルト締結について 座金寸法执よび追締めが緩 和挙動に及ほす影響. 第43回日本木材学会大 会研究発表要旨集, 盛岡, 1993, p. 605.

9) Awaludin, A., Hirai, T., Hayashikawa, T., Sasaki, Y., Oikawa, A.: One-year stress relaxation of timber joints assembled with pretensioned bolts. J. Wood Sci. 54(6), 456463 (2008)

10）桑村 仁：木材の支圧応力緩和における異方 性と圧密効果 - 鉄骨木質構造の研究 その 13 日本建築学会構造系論文集 77 (679), 14291436 (2012).

11）若島嘉朗, 清水秀丸, 藤澤泰士, 石川浩一郎：高 い初期応力を与えた木材の応力緩和挙動. 第 65回日本木材学会大会研究発表要旨集, 東京, 2015 (CD-ROM).

12）松原独歩, 島田勝廣, 西川康博, 中野貴啓, 服部 順昭：木材のボルト接合部における締付けト ルクと締付け軸力の関係. 木材工業 69(1), 1923 (2014).

13）松原独歩, 中野貴啓, 島田勝廣, 船田良, 服部順 昭：木材一ボルト接合に扔ける締付け速度が トルク係数に及ぼす影響. 木材学会誌 61(1), 33-39 (2015).

14）松原独歩, 島田勝廣, 平井卓郎, 船田良, 服部順 昭：木材一ボルト接合に扔ける座金のめり込 み挙動解析（第 1 報）弾性床上の梁理論と木 材のめり込み理論を適用した場合. 木材学会 誌 62(4), 119-132 (2016)

15）JIS B 1083 ：ねじの締付け通則, 日本規格協会 (2008).

16）JIS B 1084 ：締結用部品－締付け試験方法, 日 本規格協会 (2008).

17）JIS B 4650：手動式トルクレンチ. 日本規格協 会 (2002). 